\title{
WOMEN'S EMPOWERMENT AND GENDER INEQUALITY IN ADOLESCENT NUTRITIONAL STATUS: EVIDENCE FROM THE INDONESIAN FAMILY LIFE SURVEY
}

\author{
YOHANES SONDANG KUNTO*^¹ AND HILDE BRAS* \\ *Wageningen School of Social Sciences, Wageningen University \& Research, The \\ Netherlands and $\uparrow$ Faculty of Economics, Petra Christian University, Indonesia
}

\begin{abstract}
Summary. In contrast to the extensive knowledge on the association between women's empowerment and the nutritional status of children under the age of five, relatively little is known about the influence of women's empowerment on adolescents' nutritional status. This study aimed to assess the association between women's empowerment and gender inequalities in adolescent nutritional status. Data were from the Indonesian Family Life Survey (IFLS) covering the period 1997 to 2015, and consisted of 16,683 observations from 13,396 adolescents between the ages of 10 and 19 years born in 6781 families. Three indicators of women's empowerment were used: mother's education, mother's bargaining power and mother's working status. Multivariate linear regression with robust standard errors was used to examine whether and how these indicators of women's empowerment influenced adolescent nutritional status. Interaction terms were added to analyse how the association between women's empowerment and adolescent nutritional status differed by gender. The results showed that mother's education and mother's working status were significantly associated with adolescent nutritional status, particularly with height-for-age. Adolescents of well-educated mothers had a higher height-forage while those who were raised by mothers with a blue-collar job had a lower height-for-age. Although no gender differences were found for heightfor-age, gender differences for BMI-for-age were obvious, with boys having a lower BMI-for-age than girls. Interactions between indicators of mother's empowerment and gender showed that the gender gap in BMI-for-age was smaller for adolescents of more educated mothers. However, further analyses of food consumption patterns showed that boys whose mothers were more educated consumed more fast food and had higher instant noodle consumption than girls, thus suggesting gender bias in new disguise.
\end{abstract}

\footnotetext{
${ }^{1}$ Corresponding author. Email: yohanes.kunto@wur.nl
} 


\section{Introduction}

Previous research has extensively shown that women's empowerment has a significant influence on the nutritional status of children under the age of five (Smith, 2003; Miller \& Rodgers, 2009; Cunningham et al., 2015). Empowered mothers are thought to have more awareness, capacity and opportunities to articulate not only pro-child but also gendersensitive behaviour linking to child nutritional status. Maternal education, for example, has been found to improve child nutrition through efficient use of information related to health knowledge (Thomas et al., 1991; Glewwe, 1999; Semba et al., 2008). Furthermore, education may increase women's opportunities to participate in the labour force and heighten their contribution to the family economy, thereby increasing their voice in intrahousehold bargaining processes (Sen, 2001). Research has also found that, in most cases, both mother's working status and her bargaining power are positively correlated with their children's nutritional status (Toyama et al., 2001; Shroff et al., 2011; Roshita et al., 2013). Several studies have also reported that empowered mothers were able to reduce inequality in nutritional status between boys and girls (Skoufias, 1999; Khatun et al., 2004; Bose, 2011). For example, Bose (2011) showed that Indian mothers with a job were able to provide more protein-rich food to improve the nutrition of their undernourished daughters, thus compensating the existing gender gap. However, whether these pro-child and gender-sensitive effects of women's empowerment on child nutritional status still hold when children develop into adolescents is less well understood.

The life stage of adolescence (approximately 10-19 years) has certain characteristics that are different from childhood. During this life stage, boys and girls are exposed to a broader social environment beyond their family (Viner et al., 2012). Adolescents have more opportunities to express their preferences regarding nutrition and become more independent from their mother's food provision and supervision. However, the period of adolescence is often neglected as adolescents have typically been considered a low-risk group for poor health and have therefore received few health care resources and scant attention (The Lancet, 2013). Undernutrition among adolescents, and its gendered pattern, is not uncommon, particularly in developing countries in Asia (World Health Organization, 2006). In rural Bangladesh, the prevalence of wasting (low BMI-for-age) was found to be higher among boys than among girls (75\% vs 59\%) (Shahabuddin et al., 2000). Furthermore, in India, boys were found more likely to be stunted than girls when they entered late adolescence (at 17 years: $59.7 \%$ of boys vs $37.2 \%$ of girls) (Vijayaraghavan et al., 2000). A similar pattern has been observed in Indonesia, where more than $37 \%$ of all 18-year-old Indonesian boys were found to have experienced stunting in 2013 - a figure that was 11 percentage points higher than that of girls of the same age (Ministry of Health Republic of Indonesia, 2013). Such gender inequalities in adolescent nutritional status are very different from what has been found in studies of children under the age of five, where girls usually have a poorer nutrition and health condition than boys (Pande, 2003; Khatun et al., 2004). Interestingly, undernourishment in adolescent boys has often been found in regions where son preference is the norm (Kevane \& Levine, 2000; Koolwal, 2007; Dasgupta, 2016). The distinctive characteristics of the adolescent life stage, and the shifting gender inequalities that may occur during this period, offer an opportunity to advance knowledge on the association between women's empowerment and the nutritional status of children beyond childhood. 
This study focused on three indicators of women's empowerment that have been found to be meaningful in recent studies: mother's education, mother's bargaining power and mother's working status (Phan, 2016). Height-for-age and BMI-for-age were used as outcome variables measuring adolescent nutrition. The analytical sample was derived from the Indonesian Family Life Survey (IFLS) covering the period 1997-2015. Being a modernizing middle-income South-East Asian country and the fourth largest country in the world in terms of population, Indonesia offers an interesting case since it exhibits both traditional South-East Asian and increasingly modern and globalized characteristics.

\section{Women's empowerment and child and adolescent nutritional status}

The literature on women's empowerment and its effects on social and health behaviours varies when it comes to defining what exactly women's empowerment is. Proposed definitions diverge according to the domain of empowerment and in the emphasis placed on certain aspects. Kabeer (1999, p. 437), for example, defined empowerment as 'the expansion in people's ability to make strategic life choices in a context where this ability was previously denied to them'. Most definitions in the literature have linked women's empowerment with notions of power, agency, control and decision-making, which underline the opportunities of women to make choices and the ability to manage their lives (Cunningham et al., 2015). Malhotra and Schuler (2005) produced a thorough review with the aim of signalling and developing common indicators of women's empowerment. This review, as well as other studies (Odutolu et al., 2003; Mosedale, 2005), clearly showed that women's empowerment is highly context-specific, so constructing common indicators is problematic. However, some indicators of women's empowerment have constantly re-emerged in recent studies. These are mother's education, mother's bargaining power and mother's working status (Cunningham et al., 2015; Burroway, 2016; Phan, 2016). The capacity that empowered mothers have to manage their lives not only pertains to themselves but may also encompass the lives of other family members, including their children.

Very few studies have examined the link between women's empowerment and the nutritional status of adolescent children. However, many studies have linked indicators of women's empowerment with under-five children's nutritional status. First, an often evoked mechanism focuses on the positive effects of mother's education on children's health outcomes (Thomas et al., 1991; Glewwe, 1999; Semba et al., 2008). It is usually inferred that the more years the mother spends in education, the better she is prepared to enter the labour market and to find a better-paid job. Moreover, it is also assumed that maternal schooling indirectly improves her access to information on sound health practices and behaviour (Burroway, 2016). Better-educated mothers are thought to benefit their children through effective health-care utilization and openness to new diets and nutrition (Smith \& Haddad, 2000; Smith, 2003). Secondly, empowerment is often equated with women's working status. Work, and the remunerative benefits that go with it, give women economic independence and increase their contribution to household resources, including their children's nutritional and health needs. Sen (2001) suggested that mother's working status also increases their control over household income and resources and raises their voice in intra-household bargaining processes around these resources. However, women's work may also have negative consequences for child health because of the more limited time that mothers can spend with their children and 
the lower level of supervision they can give to what their children eat and the activities they do (Engle et al., 1999; Cunningham et al., 2015). Such lack of care may negatively affect children's nutritional status. This negative effect is thought to be even worse for children who live in poor households where mothers have to work in low-paid jobs with long working hours to contribute to the family income (Toyama et al., 2001; Roshita et al., 2013). A third mechanism through which women's empowerment may influence child nutrition is bargaining power. Richards et al. (2013) and Thomas et al. (2002) have argued that mother's bargaining power positively correlates with pro-child resource flows. An example, although not directly related to nutritional status, is a study in Benin that showed that mother's income increased her bargaining power to spend money on children's bed-nets to protect them from malaria (Rashed et al., 1999). In general, previous empirical research has found positive effects of women's empowerment on child nutrition. However, as has also been argued, these findings should be interpreted with care because spurious correlations may occur due to empowered mothers usually coming from better-off households, which could overstate the effect of women's empowerment on health behaviour and children's health outcomes (Parashar, 2005).

While studies on the association between women's empowerment and child nutritional status abound, literature discussing gender differences therein are far fewer. However, the three studies that the authors are aware of, which have studied the gendered link between women's empowerment and child nutritional status, showed interesting findings that require further research (Skoufias, 1999; Khatun et al., 2004; Bose, 2011). Skoufias (1999) studied whether the number of years that the mothers spend in school affects the weight-for-age of under-five children in Indonesia. The study found that the girls' nutrition lag to the boys (at ages 2-5 years) was much reduced if the mother had more than 12 years of schooling. Khatun (2004) reported that the BRAC (Bangladesh Rural Advancement Committee) initiatives on microcredit and education provision to empower poor women strengthened their economic opportunities and benefited their undernourished daughters. During the three surveys rounds, the study found that the proportion of stunting for an average 4-year-old girl had decreased from $74.1 \%$ in the first round (June-August 1995) to $70.4 \%$ in the third round (January-May 1996), reducing the gap to only $2.2 \%$ when compared with boys of the same age. The study inferred that despite the households' low socioeconomic status, the BRAC initiatives successfully raised mothers' awareness on gender-sensitive behaviour to feeding boys and girls equally. Bose (2011) showed that in India, where a cultural norm of son preference prevails, girls under the age of five had a poorer nutritional status than boys. The study indicated that, on average, these girls consumed fewer milk products and animal-source foods (e.g. meat, fish and eggs) compared with boys. However, in households where the mother had a job, girls were given more meat, fish and eggs, although not more milk products, thus indicating more equality in food distribution among sons and daughters.

\section{The Indonesian context}

Located in South East Asia, Indonesia is the fourth largest country in the world in terms of population. The world's largest archipelago is home to 250 million people of different religions and ethnic groups (Badan Pusat Statistik, 2011). More than $87 \%$ of Indonesians are Muslims. The Javanese and Sundanese are the two largest ethnic 
groups, comprising $40 \%$ and $15 \%$ of the population, respectively. Approximately $65 \%$ of the Indonesian population live on the islands of Java and Bali, which are more developed compared with other islands in Indonesia. After the late 1990s Asian Economic Crisis, Indonesia underwent major economic development. The emerging economy's GNI (Gross National Income) grew nearly six-fold from US\$580 in 2000 to US\$3440 in 2015 (World Bank, 2017). However, this vast economic growth was unable to elevate the country from undernutrition. The 2013 Basic Health Research report showed that more than half of Indonesian adolescents had a dietary intake of less than the national RDA (Recommended Dietary Allowance). The report also showed that among late adolescents, $31.4 \%$ were stunted and 9.4\% had a lean Body Mass Index (BMI) (Ministry of Health Republic of Indonesia, 2013).

A large regional variation in gender norms and sex imbalance exists in Indonesia, but there is less evidence of son preference than in many other Asian societies (Guilmoto, 2015). Indonesia, in general, has a bilateral kinship system and therefore women have a relatively high status (Stoler, 1977; Frankenberg \& Thomas, 2001). In fact, the history of female rulers in Indonesia can be traced back to the ancient kingdom of Majapahit hundreds of years preceding the colonial era (George, 1968). The diverse religions, ethnicities and cultures of Indonesia do not seem to undervalue women's status, as is indicated in bride prices, residence patterns after marriage and inter-racial unions (Reid, 1988). There is some evidence of gender gaps in education in the past, but in recent years gender differences have diminished in primary education and are starting to narrow in secondary education (Kevane \& Levine, 2000). A strong conditioning in gender roles took place when the New Order regime ruled the country from 1968 to 1998 . The regime encouraged family planning and promoted the 'small family norm', consisting of husband and wife with two children, to accelerate the nation's development (Niehof \& Lubis, 2003). This norm centred on the father as the main income earner and the mother as the husband's supporter, the nurturer and the social and moral caretaker of the family (Rodenburg et al., 2000), thus shaping the gendered division of labour within the family that exists today. This, to some extent, restricts women's space outside the household, but gives them much authority in domestic matters.

Research specifically discussing gender gaps in nutritional status in Indonesia is rare. Although the differences have not always been found to be statistically significant, studies on nutritional status in Indonesia have indicated that males often have a lower nutritional status than females. Sujarwoto and Tampubolon (2013), for example, showed that compared with girls of an average age of 5.9 years, boys of the same age were $-0.075 \mathrm{SD}$ (standard deviations) shorter in terms of height-for-age and - $0.003 \mathrm{SD}$ thinner in terms of weight-for-age. The Ministry of Health Republic of Indonesia (2013) indicated that boys were more at risk of being undernourished as stunting at 18 years of age was more common among boys than among girls (boys: $37.4 \%$; girls: $26.2 \%$ ). A small-scale study in Bogor and Indramayu districts also indicated that males were thinner than females in adulthood (Riyadi et al., 2006). This study found that $14.3 \%$ of adult males in poor households in Bogor had a BMI of less than 18.5, compared with 12.3\% of adult females.

\section{Study hypotheses}

The mother empowerment-child nutrition link during childhood may be expected to continue into adolescence, though becoming less strong. Thus Hypothesis I proposed 
that 'Indicators of women's empowerment (mother's education, working status and bargaining power) have positive effects on adolescent nutritional status. However, mother's working status may also have negative consequences because women have less time to supervise their children's eating habits and food consumption.'

Indonesia has a bilateral kinship system, but instead of equal nutritional status, research has shown that adolescent boys are undernourished (Ministry of Health Republic of Indonesia, 2013), thus indicating gender inequality in nutritional status during adolescence. It would be interesting to know whether women's empowerment compensated such gender inequality in similar ways as has been found in studies of under-five children in Indonesia, Bangladesh and India (Skoufias, 1999; Khatun et al., 2004; Bose, 2011). Considering that women's empowerment may increase a mother's awareness, capacity and opportunity to articulate gender-sensitive behaviour, Hypothesis II proposes that 'The gender gaps in nutritional status between boys and girls are less for adolescents whose mothers are more empowered'.

\section{Methods}

Data came from the Indonesian Family Life Survey (IFLS), which is the largest ongoing panel survey in Indonesia, collecting a wide array of data on socioeconomic and health indicators on individuals, households and communities. The first wave of the survey was conducted in 1993/1994. Since then, four follow-up surveys have been undertaken in 1997/1998, 2000, 2007/2008 and 2014/2015. The IFLS sampling scheme consists of the thirteen most densely populated provinces in Indonesia representing 83\% of the 1993 Indonesian population. The sample for IFLS-1 (1993/1994) consisted of data from 33,081 individuals living in 7224 households. The follow-up IFLS waves also collected data from new members of these households, including newborns, and also from split-off households, which mostly consisted of those who were then married and who had established a family outside the original household. The re-contact rate in IFLS-5 (2014/ 2015) was $92 \%$ of all households in IFLS-1 (1993/1994), including its split-offs. This high re-interview rate contributed significantly to the data quality as the high rates lessened the risk of bias due to non-random attrition. Strauss et al. (2016) documented the IFLS in detail.

The IFLS dataset contained data from 83,700 individuals participating in at least one of the IFLS waves. The data allowed the biological parents of 37,375 individuals to be traced. Because the variable of interest was nutritional status in adolescence (ages 10-19 years), 19,224 individuals whose height and weight measurements were not collected at that age were excluded. A further 179 adolescents whose height-for-age and BMI-for-age were biologically implausible according to the WHO growth reference chart were also excluded (Onis et al., 2007). These exclusions produced an initial sample of 25,278 observations from 17,972 adolescents born in 8687 families. The inclusion of the explanatory variables and control variables in the analyses reduced the sample further. This study excluded 3153 adolescents due to missing values on indicators of women's empowerment, particularly because the indicator for mother's bargaining power was available from IFLS-2 (1997/ 1998) onwards only. Therefore, all observations from IFLS-1 (1993/1994) were excluded. A further reduction of 1423 adolescents due to missing values in the control variables, mainly because the father was absent during the collection of height and weight measurements, 
completed the sample construction. Therefore, the final analytical sample consisted of 16,683 observations from 13,396 adolescents born in 6781 families.

\section{Outcome variables}

There were two outcome variables: adolescent nutritional status (height-for-age and BMI-for-age) and food consumption. Adolescent nutritional status was the primary outcome variable used to test the proposed hypotheses. The additional food consumption variable was analysed to understand the underlying causes of the expected reduced gender gaps in nutritional status among adolescents of empowered mothers.

In each IFLS wave, trained nurses were assigned to collect multiple health measurements of household members who were present during the survey. The measurements included height $(\mathrm{cm})$ and weight $(\mathrm{kg})$ up to a single digit decimal. For indicators of adolescent nutritional status, height and weight were standardized into height-for-age and BMI-for-age based on the WHO child's growth references (Onis et al., 2007). This $Z$-score standardization controlled biological variations in growth and produced linear indicators that were more comparable across gender and age (Wang \& Chen, 2012). The standardization also simplified identification of biologically implausible heights and BMI measures. It is worth noting that height-for-age reflects long-term nutritional status, which is partly inherited from earlier life stages, while BMIfor-age reflects current nutritional status and is more sensitive to the life circumstances experienced at adolescence. Other anthropometric-related nutritional status indicators such as weight-for-length and weight-for-age were not used because these were only available for children under the age of 5 and children under the age of 10, respectively.

Data on food consumption were available in the last three waves, starting from IFLS-3 (2000). This basic information on food consumption recorded the number of days an individual was consuming particular types of food in the last week before the interview. The IFLS-3 (2000) and IFLS-4 (2007/2008) collected data on ten food types, including sweet potatoes, eggs, fish, meat, dairy products, green leafy vegetables, banana, papaya, carrot and mango. In IFLS-5 (2014/2015), another seven food types were added, consisting of fast food, instant noodles, soft drinks, chilli sauce, fried snacks, rice and sweet snacks. The number of days in IFLS-3 (2000) were re-scaled to harmonize the data with the continuous scale on the number of days that more recent IFLS waves used: $0=$ did not consume; $1=1$ day; $2.5=2$ to 3 days; $5=4$ to 6 days; and $7=$ every day. Since adolescents rarely consumed all these food types in a week, the fourteen food types were aggregated into eight food groups consisting of animal-source foods (eggs, fish, meat), vegetables (green leafy vegetables, carrot), fruits (banana, papaya, mango), dairy products, fast foods, instant noodles, soft drinks and snacks (fried snacks, sweet snacks). Sweet potatoes, rice and chilli sauce were not included because the first two are carbohydrate sources, which most Indonesian adolescents eat at least once a day, and chilli sauce is an additional dish that is consumed only in small portions, and therefore the effect on nutritional status would be minor, if existing at all.

\section{Explanatory variables}

The key explanatory variables were 'gender' and 'women's empowerment'. The gender variable was constructed using 'girls' as the reference group because in Indonesia 
adolescent boys are expected to experience undernutrition. Women's empowerment had three indicators: mother's education, mother's bargaining power and mother's working status. Mother's education was measured as the number of years of schooling completed, given on a continuous scale ranging between 0 and 12 years of schooling. Mother's bargaining power indicates the mother's voice in power relations with other family members in household decision-making. It was constructed from the IFLS 'household expenditure and use of time' module (Frankenberg \& Thomas, 2001). This originally consisted of seventeen questions, but since households did not make decisions on all items, only thirteen questions with the fewest missing values were used. These questions included decision-making on food consumed at home, daily purchases (e.g. cleaning supplies), the mother's clothes, the father's clothes, the children's clothes, the children's education, the children's health, large expensive purchases (e.g. fridge or TV), giving money to the mother's parents/family, giving money to the father's parents/family, gifts for parties/weddings, time that the mother could spend socializing and whether the mother was allowed to work outside the household. For each question, the authors assigned ' 0 ' if the mother did not contribute towards making a decision, ' 1 ' if she did contribute, but did so jointly with other members of the household, and ' 2 ' if she took the decision alone. By using a similar approach to that of Shroff et al. (2011), the first PCA (Principle Component Analysis) factor score from the thirteen questions was assigned as the composite value for mother's bargaining power. A dummy variable was used to categorize mother's working status and distinguish between mothers who did not work and those who had a job. However, since the association of mother's working status and adolescent nutritional status may also have differed by the mother's type of job, another dummy was constructed to specify whether the mother's job was blue-collar or white-collar. Mothers who worked as an 'unpaid family worker', 'casual worker in agriculture' or 'casual worker in non-agriculture' were classified into the blue-collar category, and those who worked as 'professional/self-employed', 'government worker' and 'private worker' were classified into the white-collar category.

\section{Control variables}

Six groups of control variables were included to reduce estimations bias on nutritional status due to possible confounders: 1) mother's and the father's height and BMI to control for genetic factors; 2) Personal Consumption Expenditure (PCE) to control for family socioeconomic status (SES); 3) birth order and sibling size to control for family composition; 4) adolescents' activity to control for energy expenditure; 5) residential area to control for regional differences; and 6) IFLS wave fixed-effects to control for socioeconomic changes over the period of the study.

Genetic factors unarguably influence a person's height and weight (Silventoinen et al., 2007; Liu et al., 2015). The inclusion of mother's and the father's height and BMI as control variables is expected to reduce variations in nutritional status due to genetic factors inherited from both parents.

Other factors, such as the family SES, may also have affected nutritional status (Thomas, 1994; Engle et al., 1999; Heilmann, 2013). A greater level of disposable family income may increase access to quality food and health facilities and provide a better living environment. The IFLS collected data on expenditure and assets, which can be used to construct a family socioeconomic status (SES) indicator. Filmer and Pritchett (2001) 
suggested that, when expenditure and asset data are available, the use of expenditure for the family SES indicator is preferable. This study closely followed Witoelar (2009) to calculate the nominal Personal Consumption Expenditure (PCE) from the IFLS data. With a similar approach to that described in Beegle et al. (1999) and Strauss et al. (2004), the real PCE in million Rupiah (1 million Rupiah $=$ US\$83,77 in 2014) was calculated by using 2014 prices in the capital city Jakarta as the baseline. The use of real PCE ensured comparability of family SES across regions (robust to regional price differences) and across IFLS waves (robust to the inflation rate).

Related to family SES, the share of resources (financial, goods, time, etc.) that a person received may have differed by family composition factors such as birth order and sibling size (Bronte-Tinkew \& Dejong, 2004; Bras et al., 2010; Stradford et al., 2016). For this reason, birth order and sibling size were also included as control variables. Dummies were used for birth order and a continuous scale for sibling size to reduce potential multicollinearity between the two variables (Booth \& Kee, 2009). Sibling size represents the number of all living biological children ( $0-9$ years old) and adolescents (10-19 years old) of a family in each IFLS wave.

Previous studies showed that the burden of attending school and working might put the health of school-age children at risk, particularly if their food consumption does not match energy-demanding activities (Wolff \& Maliki, 2008; Gumus \& Wingenbach, 2016). Dummies for adolescents' activities to control for differences in energy expenditure were therefore included. The IFLS recorded whether a person was involved in school and work activity in the last month before the survey. This activity was coded into dummies consisting of four categories: 'neither went to school nor work', 'went to school only', 'went to work only' and 'went to school and work'.

Regional difference is another important factor that affects health (Suryadarma et al., 2006), possibly through spatial differences in food availability and access to health facilities. Residential area variables were used to control for regional differences and a dummy was included for urban/rural residence, and another for residence on Java/Bali versus other regions.

Apart from the above factors, another important factor that may have influenced nutritional status is socioeconomic change (Cai, 2014; Delfino et al., 2016). This macro factor is multidimensional, including, but not limited to, transitions in nutrition and dietary practices, such as the global nutrition transition (Popkin et al., 2012) and improvements in health facilities over time. Dummies were included to represent the IFLS waves as year fixed-effects to control for socioeconomic changes.

Analysis

First, the two proposed hypotheses were examined, then an exploratory analysis was undertaken to further understand the linkages between women's empowerment and gender differences in food consumption.

The basic model was as follows:

$$
Y_{i m}=\beta_{1} \operatorname{sex}_{i m}+\beta_{2} X_{i m}+\varepsilon_{i m}
$$

(Model 1)

where $Y_{i m}$ is the nutritional status of adolescent $i$ born in family $m$; $\operatorname{sex}_{i m}$ is the adolescent's sex and $X_{i m}$ is a control variable. Model 1 was estimated to examine 
whether there were any gender inequalities in nutritional status during adolescence. Stepwise inclusion of each indicator of women's empowerment followed the basic model and produced three models with main effects of women's empowerment as follows:

$$
\begin{aligned}
& Y_{i m}=\beta_{1} \operatorname{sex}_{i m}+\beta_{2} \operatorname{medu}_{m}+\beta_{3} X_{i m}+\varepsilon_{i m} \\
& Y_{i m}=\beta_{1} \operatorname{sex}_{i m}+\beta_{2} \operatorname{medu}_{m}+\beta_{3} \text { mbargain }_{m}+\beta_{4} X_{i m}+\varepsilon_{i m} \\
& Y_{i m}=\beta_{1} \operatorname{sex}_{i m}+\beta_{2} \text { medu }_{m}+\beta_{3} \text { mbargain }_{m}+\beta_{4} \text { mwork }_{m}+\beta_{5} X_{i m}+\varepsilon_{i m}
\end{aligned}
$$

where $\operatorname{medu}_{m}$ is mother's education, $\operatorname{mbargain}_{m}$ is mother's bargaining power and mwork $_{m}$ is mother's working status. Models 2 to 4 were estimated to examine whether women's empowerment positively correlated with adolescent nutritional status (Hypothesis I). Further stepwise inclusions of interactions between women's empowerment and gender were then performed. The models with interactions were estimated to examine whether gender inequalities in nutritional status were less for adolescents of empowered mothers (Hypothesis II). This process produced Models 5 to 7 as follows:

$$
\begin{aligned}
Y_{i m}= & \beta_{1} \operatorname{sex}_{i m}+\beta_{2} \text { medu }_{m}+\beta_{3} \text { mbargain }_{m}+\beta_{4} \text { mwork }_{m} \\
& +\beta_{5}\left(\operatorname{sex}_{i m} \times \operatorname{medu}_{m}\right)+\beta_{6} X_{i m}+\varepsilon_{i m} \\
Y_{i m}= & \beta_{1} \operatorname{sex}_{i m}+\beta_{2} \operatorname{medu}_{m}+\beta_{3} \operatorname{mbargain}_{m}+\beta_{4} \text { mwork }_{m} \\
& +\beta_{5}\left(\operatorname{sex}_{i m} \times \operatorname{medu}_{m}\right)+\beta_{6}\left(\operatorname{sex}_{i m} \times \text { mbargain }_{m}\right)+\beta_{7} X_{i m}+\varepsilon_{i m} \\
Y_{i m}= & \beta_{1} \operatorname{sex}_{i m}+\beta_{2} \operatorname{medu}_{m}+\beta_{3} \operatorname{mbargain}_{m}+\beta_{4} \text { mwork }_{m} \\
& +\beta_{5}\left(\operatorname{sex}_{i m} \times \text { medu }_{m}\right)+\beta_{6}\left(\operatorname{sex}_{i m} \times \operatorname{mbargain}_{m}\right) \\
& +\beta_{7}\left(\operatorname{sex}_{i m} \times \text { mwork }_{m}\right)+\beta_{8} X_{i m}+\varepsilon_{i m}
\end{aligned}
$$

Multivariate linear regressions were used to estimate these seven models. The final analytical sample was nested in two ways. First, it was nested within adolescents because some adolescents were interviewed in several IFLS waves. Second, within-family nesting occurred because clusters of adolescents from the same family who had the same biological parents existed. Pepper (2002) and Cameron et al. (2011) suggested clustering the standard errors $\varepsilon_{i m}$ of such multiple nested samples at the highest level of aggregation to produce inferences that are robust to intra-cluster correlations. Since within-family clustering is the highest level of aggregation, standard errors, $\varepsilon_{i m}$, of the multivariate linear regressions were then clustered at the within-family level. The Akaike Information Criterion (AIC) was used to select the most parsimonious models for both height-for-age and BMI-for-age.

In the second part of the analyses, the sample was divided by gender in order to perform a series of exploratory analyses using two-sample $t$-tests on food consumption. These $t$-tests were performed only for women's empowerment indicators in which the interaction with gender was significant. The results were then compiled into a table consisting of the eight food groups. 


\section{Results}

\section{Sample characteristics}

Table 1 summarizes the sample characteristics. It is clear that the differences in percentage of adolescent boys and girls by IFLS wave were not significant. However, adolescents' average age did differ: those in the latest IFLS (2014/2015) were younger than those in the previous three waves (on average 14.11 years). In general, there was a significant trend of improvement in nutritional status over time. Only during the period of the Asian economic crisis did the BMI-for-age decrease slightly from $-0.69 \mathrm{SD}$ in IFLS-2 (1997/1998) to -0.76 SD in IFLS-3 (2000). Despite the improvement in adolescent nutritional status over time, their average height-for-age and BMI-for-age were negative, meaning that the nutritional status of Indonesian adolescents was still below the WHO growth reference even in 2014/2015. Thus, these numbers underlined the high share of undernourishment in Indonesia, at least among its adolescents. A significant difference in adolescent activities by IFLS wave was observed. In IFLS-3 (2000), fewer adolescents went to school than in IFLS-2 (1997/1998), indicating high rates of school drop-out, which may relate to the Asian economic crisis of the late 1990s (Frankenberg et al., 1999). The percentage of adolescents who went to school then increased again but did not recover to the level before the crisis. Interestingly, the percentage of adolescents who 'went to school and work' increased. The percentage grew almost three-fold: from $4.35 \%$ in IFLS-2 (1997/1998) to $12.9 \%$ in IFLS-5 (2014/2015). Table 1 also shows a significant decrease in the adolescents' vegetable consumption over the 15 -year period. Whereas the average number of days that adolescents consumed vegetables in a week was 3.46 in IFLS-2 (2000), the number dropped to 1.95 in IFLS-5 (2014/2015). The situation was the same for the consumption of fruits, for which consumption fell from 2.29 in IFLS-2 (2000) to 0.83 in IFLS-5 (2014/2015). Some food groups were available in IFLS-5 (2014/2015) only, and therefore no statistical test could be applied, but it should be noted that the consumption of junk food such as instant noodles and snacks was high (instant noodles: 2.24; snacks: 3.13 ).

The 'women's empowerment' subsection of Table 1 shows that mother's education increased significantly over time: from an average of 2.42 years in IFLS-2 (1997/1998) to 7.18 years in IFLS-5 (2014/2015). In contrast to the improvement in years of schooling, mother's bargaining power remained at the same level in all waves until IFLS-5 (2014/ 2015), when there was a significant increase to $0.47 \mathrm{SD}$. In addition, more women were participating in the labour force. More than $70 \%$ of all women were working in IFLS-5 (2014/2015), in contrast to 57.7\% in IFLS-2 (1997/1998).

The 'other characteristics' subsection of Table 1 shows that both parental height and BMI increased over time, indicating improvement in adult nutritional status. However, there was a trend that mothers became gradually more overweight, as mother's average BMI in IFLS-5 (2014/2015) was over 25. A trend towards smaller family size was noticeable as sibling size became smaller from 2000 onwards: from 3.10 in IFLS-3 (2000) to 2.64 in IFLS-5 (2014/2015). The Asian economic crisis might be the reason why the average real PCE was at its lowest in 2000 (IFLS-3) (i.e. 0.83 million Rupiah) before steadily increasing to 0.97 million Rupiah in IFLS-5 (2014/2015). The majority of families in the sample lived in urban areas and on Java and Bali (urban: 58.59\%; Java \& Bali: $58.86 \%$ in IFLS-5 (2014/2015)). 
Table 1. Characteristics of study sample of Indonesian mothers and adolescent children by IFLS wave

\begin{tabular}{|c|c|c|c|c|c|c|c|c|c|}
\hline \multirow[b]{2}{*}{ Characteristics } & \multicolumn{2}{|c|}{$\begin{array}{c}\text { IFLS-2 } \\
(1997 / 1998)\end{array}$} & \multicolumn{2}{|c|}{$\begin{array}{l}\text { IFLS-3 } \\
(2000)\end{array}$} & \multicolumn{2}{|c|}{$\begin{array}{c}\text { IFLS-4 } \\
(2007 / 2008)\end{array}$} & \multicolumn{2}{|c|}{$\begin{array}{c}\text { IFLS-5 } \\
(2014 / 2015)\end{array}$} & \multirow[b]{2}{*}{$p$-value } \\
\hline & Mean & $\mathrm{SD}$ & Mean & SD & Mean & SD & Mean & SD & \\
\hline \multicolumn{10}{|l|}{ Adolescents $^{\mathrm{a}}$} \\
\hline \multicolumn{10}{|l|}{ Gender } \\
\hline Boys $(\%)$ & 49.86 & & 50.68 & & 50.70 & & 51.46 & & 0.57 \\
\hline Girls (\%) & 50.14 & & 49.32 & & 49.30 & & 48.54 & & \\
\hline Age (years) & 14.25 & $(2.52)$ & 14.52 & $(2.64)$ & 14.31 & $(2.60)$ & 14.11 & $(2.51)$ & $<0.01$ \\
\hline \multicolumn{10}{|l|}{ Nutritional status } \\
\hline Height-for-age & -1.77 & $(1.03)$ & -1.77 & $(0.97)$ & -1.61 & $(1.06)$ & -1.37 & $(1.01)$ & $<0.01$ \\
\hline BMI-for-age & -0.69 & $(1.08)$ & -0.76 & $(1.09)$ & -0.66 & $(1.22)$ & -0.49 & (1.29) & $<0.01$ \\
\hline \multicolumn{10}{|l|}{ Activity } \\
\hline $\begin{array}{l}\text { Neither went to } \\
\text { school nor work }(\%)\end{array}$ & 10.03 & & 10.90 & & 8.05 & & 4.39 & & $<0.01$ \\
\hline Went to school (\%) & 79.31 & & 65.20 & & 73.30 & & 76.95 & & \\
\hline Went to work (\%) & 6.32 & & 12.68 & & 8.75 & & 5.78 & & \\
\hline $\begin{array}{l}\text { Went to school and } \\
\text { work }(\%)\end{array}$ & 4.34 & & 11.23 & & 9.89 & & 12.88 & & \\
\hline \multicolumn{10}{|l|}{$\begin{array}{l}\text { Food consumption (days } \\
\text { per week) }\end{array}$} \\
\hline Animal-source food & & & 2.19 & $(1.39)$ & 2.74 & $(1.29)$ & 2.31 & $(1.30)$ & $<0.01$ \\
\hline Vegetables & & & 3.46 & $(1.48)$ & 3.13 & $(1.56)$ & 1.95 & (1.59) & $<0.01$ \\
\hline Fruits & & & 2.29 & (1.47) & 1.24 & (1.14) & 0.83 & $(1.01)$ & $<0.01$ \\
\hline Milk & & & 1.21 & $(2.29)$ & 1.64 & $(2.41)$ & 1.38 & $(2.32)$ & $<0.01$ \\
\hline Fast food & & & & & & & 0.37 & $(1.09)$ & \\
\hline Instant noodles & & & & & & & 2.24 & $(2.12)$ & \\
\hline Soft drinks & & & & & & & 0.50 & $(1.18)$ & \\
\hline \multirow{2}{*}{\multicolumn{10}{|c|}{ Women's empowerment ${ }^{b}$}} \\
\hline & & & & & & & & & \\
\hline Mother's education & 2.42 & $(3.91)$ & 2.86 & $(4.15)$ & 5.03 & $(4.71)$ & 7.18 & $(4.22)$ & $<0.01$ \\
\hline $\begin{array}{l}\text { Mother's bargaining } \\
\text { power }\end{array}$ & 0.11 & $(1.74)$ & 0.13 & $(1.69)$ & -0.04 & $(1.52)$ & 0.47 & $(2.06)$ & $<0.01$ \\
\hline \multicolumn{10}{|l|}{ Mother's working status } \\
\hline Did not work (\%) & 42.30 & & 31.32 & & 31.87 & & 29.12 & & $<0.01$ \\
\hline Blue-collar worker (\%) & 13.59 & & 19.08 & & 29.71 & & 22.37 & & \\
\hline White-collar worker (\%) & 44.11 & & 49.60 & & 38.41 & & 48.51 & & \\
\hline \multicolumn{10}{|l|}{ Other $^{\mathrm{b}}$} \\
\hline \multicolumn{10}{|l|}{ Parental } \\
\hline Mother's height & 150.31 & $(5.36)$ & 150.35 & $(5.25)$ & 150.73 & $(5.29)$ & 151.12 & $(5.24)$ & $<0.01$ \\
\hline Mother's BMI & 23.27 & $(4.01)$ & 23.57 & $(4.05)$ & 24.60 & $(4.30)$ & 25.64 & (4.41) & $<0.01$ \\
\hline Father's height & 160.76 & $(5.85)$ & 160.78 & $(5.86)$ & 161.49 & $(6.03)$ & 162.28 & $(6.03)$ & $<0.01$ \\
\hline Father's BMI & 21.75 & $(3.14)$ & 21.86 & (3.33) & 22.59 & (3.63) & 23.16 & (3.73) & $<0.01$ \\
\hline \multicolumn{10}{|l|}{ Family } \\
\hline Sibling size & 2.86 & $(1.31)$ & 3.10 & $(1.44)$ & 2.93 & $(1.34)$ & 2.64 & $(1.15)$ & $<0.01$ \\
\hline $\begin{array}{l}\text { Real PCE (in million } \\
\text { rupiah) }\end{array}$ & 0.87 & $(2.24)$ & 0.83 & $(0.95)$ & 0.88 & $(0.81)$ & 0.97 & $(0.78)$ & $<0.01$ \\
\hline \multicolumn{10}{|l|}{ Residential area } \\
\hline Urban (\%) & 48.79 & & 46.68 & & 51.95 & & 58.59 & & $<0.01$ \\
\hline Rural (\%) & 51.21 & & 53.32 & & 48.05 & & 41.41 & & \\
\hline Java \& Bali (\%) & 62.71 & & 62.10 & & 62.56 & & 58.86 & & 0.01 \\
\hline Outside Java \& Bali (\%) & 37.29 & & 37.90 & & 37.44 & & 41.14 & & \\
\hline No. of adolescents observed ${ }^{\mathrm{a}}$ & \multicolumn{2}{|c|}{3528} & \multicolumn{2}{|c|}{4497} & \multicolumn{2}{|c|}{4124} & \multicolumn{2}{|c|}{4534} & \\
\hline No. of families observed ${ }^{\mathrm{b}}$ & & & & & & & & 52 & \\
\hline
\end{tabular}

ANOVA test used to analyse differences by IFLS waves of all continues-scale characteristics. The $\chi^{2}$ test was used to analyse association between each dummy characteristic and IFLS wave.

$\mathrm{PCE}=$ Personal Consumption Expenditure.

${ }^{a}$ Number of adolescents observed given at bottom of table.

${ }^{b}$ Number of families observed given at bottom of table.

${ }^{\text {\#} S o m e ~ o b s e r v a t i o n s ~ h a d ~ m i s s i n g ~ v a l u e s ; ~ t h e ~ a c t u a l ~ n u m b e r ~ o f ~ a d o l e s c e n t s ~ o b s e r v e d ~ i s ~ g i v e n ~ i n ~ T a b l e ~} 4$. 


\section{Multivariate linear regression}

Table 2 presents the multivariate linear regression models for the determinants of height-for-age of adolescents. The main question was whether and how the three different indicators of women's empowerment were associated with adolescents' heightfor-age. In Model 1, the gender of the adolescent and all control variables were included. This and subsequent models in Table 2 indicated that there was no significant gender difference in height-for-age. Model 1 also showed that parental characteristics were positively related to height-for-age. However, this pertained more to parental height than to BMI. The association between mother's height and adolescents' height-for-age, for example, was more than twice that of mother's BMI (e.g. mother's height vs mother's BMI: $b=0.053 ; p<0.01$ vs $b=0.023 ; p<0.01)$. Sibling size negatively influenced heightfor-age $(b=-0.068$ per sibling; $p<0.01)$; the more siblings an adolescent had, the shorter his or her height-for-age was, indicating processes of resource dilution in the family. Personal Consumption Expenditure (PCE) was positively correlated with heightfor-age $(b=0.036 ; p<0.01)$, suggesting that family SES played a significant role in improving height-for-age. No significant effect of the activity pattern of adolescents on their height-for-age was found. Those adolescents who lived in an urban area and those who lived in Java and Bali were considerably taller (urban: $b=0.199, p<0.01$; Java and Bali: $b=0.113 ; p<0.01$ ), which might indicate spatial differences in food consumptions and health services across the archipelago. Significant improvements in height-for-age in the last two waves of the IFLS also occurred, with height-for-age in IFLS-5 (2014/2015) being higher compared with that in IFLS-2 $(1997 / 1998)(b=0.176 ; p<0.01)$.

Models 2-4 in Table 2 comprise the main effects of the three empowerment indicators in a stepwise manner. Model 2 showed that mother's education had a positive effect on height-for-age $(b=0.009$ per additional year of schooling; $p<0.01)$. No significant effects were found for mother's bargaining power (Model 3). Compared with adolescents whose mother did not work, the height-for-age of adolescents who were raised by blue-collar mothers was shorter $(b=-0.064, p<0.01$ in Model 4$)$. The same association also applied to adolescents of white-collar mothers although the negative effect was much less and not significant ( $b=-0.024$ in Model 4).

Models 5 to 7 in Table 2 included interaction terms between the women's empowerment indicators and gender. However, none of these interactions was significant. Moreover, the models with interactions did not improve over Model 4, which included the main effects only, as is shown by the lowest AIC score (AIC $=43,248.204)$. Thus, Model 4 was the most parsimonious model.

Table 3 shows the multivariate regression analyses for adolescents' BMI-for-age. In contrast to height-for-age, the models strongly indicated gender differences in BMI-forage. Model 1 suggested that boys were thinner than girls in terms of BMI-for-age $(b=-0.313, p<0.01)$. Model 1 also suggested a positive effect of mother's and father's BMI on the adolescents' BMI-for-age (mother's BMI: $b=0.059, p<0.01$; father's BMI: $b=0.073, p<0.01)$. Such significant effects were not found for mother's and father's height. Sibling size was negatively associated with BMI-for-age $(b=-0.030$ per sibling, $p<0.01$ ). Personal Consumption Expenditure (PCE) positively influenced BMI-for-age as each additional one million Rupiah increased the BMI-for-age by 0.024 SD $(b=0.024$, $p<0.05)$. Adolescents' activities had a significant impact on their BMI-for-age. 
Table 2. Multivariate linear regression for height-for-age of Indonesian adolescents

\begin{tabular}{|c|c|c|c|c|c|c|c|c|c|c|c|c|c|c|}
\hline & \multicolumn{2}{|c|}{ Model 1} & \multicolumn{2}{|c|}{ Model 2} & \multicolumn{2}{|c|}{ Model 3} & \multicolumn{2}{|c|}{ Model 4} & \multicolumn{2}{|c|}{ Model 5} & \multicolumn{2}{|c|}{ Model 6} & \multicolumn{2}{|c|}{ Model 7} \\
\hline & Coef. & SE & Coef. & SE & Coef. & SE & Coef. & SE & Coef. & SE & Coef. & SE & Coef. & SE \\
\hline \multicolumn{15}{|l|}{ Gender } \\
\hline Girls (Ref.) & & & & & & & & & & & & & & \\
\hline Boys & -0.007 & $(0.015)$ & -0.009 & $(0.015)$ & -0.009 & $(0.015)$ & -0.010 & $(0.015)$ & -0.025 & $(0.021)$ & -0.026 & $(0.021)$ & -0.043 & $(0.029)$ \\
\hline \multicolumn{15}{|l|}{ Women's empowerment } \\
\hline Mother's education & & & 0.009 & $(0.002)^{* *}$ & 0.009 & $(0.002)^{* *}$ & 0.008 & $(0.002)^{* *}$ & 0.007 & $(0.003) *$ & 0.007 & $(0.003)^{*}$ & 0.007 & $(0.003)^{*}$ \\
\hline Mother's bargaining power & & & & & 0.000 & $(0.004)$ & 0.000 & $(0.004)$ & 0.000 & $(0.004)$ & -0.005 & $(0.006)$ & -0.004 & $(0.006)$ \\
\hline \multicolumn{15}{|l|}{ Mother's working status } \\
\hline \multicolumn{15}{|l|}{ Did not work (Ref.) } \\
\hline Blue-collar worker & & & & & & & -0.064 & $(0.023)^{* *}$ & -0.064 & $(0.023)^{* *}$ & -0.064 & $(0.023)^{* *}$ & -0.073 & $(0.029)^{*}$ \\
\hline White-collar worker & & & & & & & -0.024 & $(0.019)$ & -0.024 & $(0.019)$ & -0.024 & $(0.019)$ & -0.040 & $(0.024)$ \\
\hline \multicolumn{15}{|l|}{ Boys $x$ women's empowerment } \\
\hline Mother's education & & & & & & & & & 0.003 & $(0.003)$ & 0.003 & $(0.003)$ & 0.003 & $(0.003)$ \\
\hline Mother's bargaining power & & & & & & & & & & & 0.010 & $(0.008)$ & 0.009 & $(0.008)$ \\
\hline \multicolumn{15}{|l|}{ Mother's working status } \\
\hline \multicolumn{15}{|l|}{ Did not work (Ref.) } \\
\hline Blue-collar worker & & & & & & & & & & & & & 0.018 & $(0.039)$ \\
\hline White-collar worker & & & & & & & & & & & & & 0.030 & $(0.033)$ \\
\hline \multicolumn{15}{|l|}{ Control variables } \\
\hline Mother's height & 0.053 & $(0.002)^{* *}$ & 0.053 & $(0.002)^{* *}$ & 0.053 & $(0.002)^{* *}$ & 0.053 & $(0.002)^{* *}$ & 0.053 & $(0.002)^{* *}$ & 0.053 & $(0.002)^{* *}$ & 0.053 & $(0.002)^{* *}$ \\
\hline Mother's BMI & 0.023 & $(0.003)^{* *}$ & 0.022 & $(0.003)^{* *}$ & 0.022 & $(0.003)^{* *}$ & 0.022 & $(0.003)^{* *}$ & 0.022 & $(0.003)^{* *}$ & 0.022 & $(0.003)^{* *}$ & 0.022 & $(0.003)^{* *}$ \\
\hline Father's height & 0.042 & $(0.002)^{* *}$ & 0.042 & $(0.002)^{* *}$ & 0.042 & $(0.002)^{* *}$ & 0.042 & $(0.002)^{* *}$ & 0.042 & $(0.002)^{* *}$ & 0.042 & $(0.002)^{* *}$ & 0.042 & $(0.002)^{* *}$ \\
\hline Father's BMI & 0.023 & $(0.002)^{* *}$ & 0.022 & $(0.002)^{* *}$ & 0.022 & $(0.002)^{* *}$ & 0.022 & $(0.002)^{* *}$ & 0.022 & $(0.002)^{* *}$ & 0.022 & $(0.002)^{* *}$ & 0.022 & $(0.002)^{* *}$ \\
\hline Sibling size & -0.068 & $(0.007)^{* *}$ & -0.068 & $(0.007)^{* *}$ & -0.068 & $(0.007)^{* *}$ & -0.069 & $(0.007) * *$ & -0.069 & $(0.007)^{* *}$ & -0.069 & $(0.007)^{* *}$ & -0.069 & $(0.007)^{* *}$ \\
\hline PCE (million Rupiah) & 0.036 & $(0.014)^{*}$ & 0.034 & $(0.014)^{*}$ & 0.034 & $(0.014)^{*}$ & 0.034 & $(0.014)^{*}$ & 0.034 & $(0.014)^{*}$ & 0.034 & $(0.014)^{*}$ & 0.034 & $(0.014)^{*}$ \\
\hline \multicolumn{15}{|l|}{ Adolescent activity } \\
\hline \multicolumn{15}{|l|}{$\begin{array}{l}\text { Neither went to school } \\
\text { nor work (Ref.) }\end{array}$} \\
\hline Went to school only & 0.007 & $(0.026)$ & -0.007 & $(0.027)$ & -0.007 & $(0.027)$ & -0.005 & $(0.027)$ & -0.004 & $(0.027)$ & -0.004 & $(0.027)$ & -0.004 & $(0.027)$ \\
\hline Went to work only & 0.028 & $(0.031)$ & 0.032 & $(0.031)$ & 0.032 & $(0.031)$ & 0.039 & $(0.031)$ & 0.041 & $(0.031)$ & 0.040 & $(0.031)$ & 0.041 & $(0.031)$ \\
\hline $\begin{array}{l}\text { Went to school and } \\
\text { work }\end{array}$ & 0.048 & $(0.034)$ & 0.039 & $(0.034)$ & 0.039 & $(0.034)$ & 0.051 & $(0.034)$ & 0.052 & $(0.034)$ & 0.052 & $(0.034)$ & 0.052 & $(0.034)$ \\
\hline
\end{tabular}




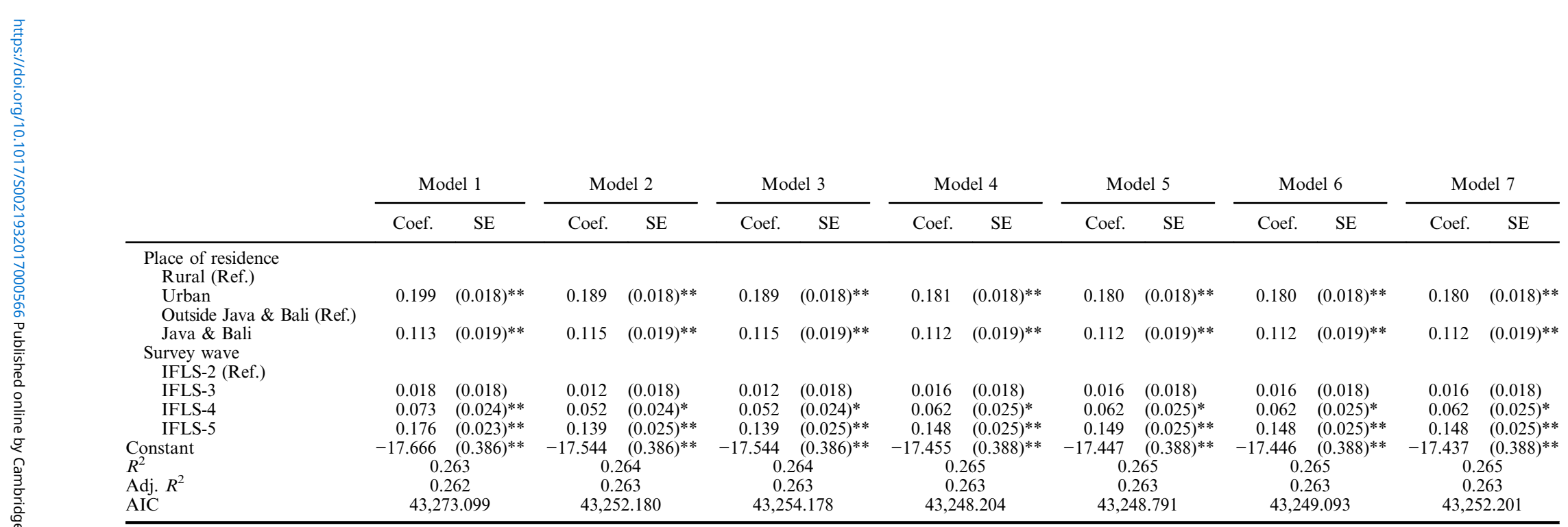

Coef. = regression coefficient; $\mathrm{SE}=$ standard error; Ref. = reference category. PCE = Personal Consumption Expenditure.

No. observations $=16,683$; No. adolescents $=13,396$; No. families $=6781$.

Birth order dummies were used in the analysis but were not included in the tables to save space.

${ }^{*} p<0.05 ;{ }^{* *} p<0.01$. 
Table 3. Multivariate linear regression for BMI-for-age of Indonesian adolescents

\begin{tabular}{|c|c|c|c|c|c|c|c|c|c|c|c|c|c|c|}
\hline & \multicolumn{2}{|c|}{ Model 1} & \multicolumn{2}{|c|}{ Model 2} & \multicolumn{2}{|c|}{ Model 3} & \multicolumn{2}{|c|}{ Model 4} & \multicolumn{2}{|c|}{ Model 5} & \multicolumn{2}{|c|}{ Model 6} & \multicolumn{2}{|c|}{ Model 7} \\
\hline Coef. & & SE & Coef. & SE & Coef. & SE & Coef. & SE & Coef. & SE & Coef. & SE & Coef. & SE \\
\hline \multicolumn{15}{|l|}{ Gender } \\
\hline \multicolumn{15}{|l|}{ Girls (Ref.) } \\
\hline Boys & -0.313 & $(0.019)^{* *}$ & -0.314 & $(0.019)^{* *}$ & -0.314 & $(0.019)^{* *}$ & -0.313 & $(0.019)^{* *}$ & -0.406 & $(0.026)^{* *}$ & -0.404 & $(0.026)^{* *}$ & -0.394 & $(0.037)^{* *}$ \\
\hline \multicolumn{15}{|l|}{ Women's empowerment } \\
\hline Mother's education & & & 0.003 & $(0.003)$ & 0.004 & $(0.003)$ & 0.003 & $(0.003)$ & -0.007 & $(0.003)^{*}$ & -0.008 & $(0.003)^{*}$ & -0.008 & $(0.004)^{*}$ \\
\hline Mother's bargaining power & & & & & -0.004 & $(0.005)$ & -0.005 & $(0.005)$ & -0.005 & $(0.005)$ & 0.003 & $(0.007)$ & 0.002 & $(0.007)$ \\
\hline \multicolumn{15}{|l|}{ Mother's working status } \\
\hline \multicolumn{15}{|l|}{ Did not work (Ref.) } \\
\hline Blue-collar worker & & & & & & & 0.050 & $(0.029)$ & 0.050 & $(0.029)$ & 0.050 & $(0.029)$ & 0.050 & $(0.037)$ \\
\hline White-collar worker & & & & & & & 0.047 & $(0.024)$ & 0.045 & $(0.024)$ & 0.045 & $(0.024)$ & 0.058 & $(0.031)$ \\
\hline \multicolumn{15}{|l|}{ Boys $\times$ women's empowerment } \\
\hline Mother's education & & & & & & & & & 0.021 & $(0.004)^{* *}$ & 0.021 & $(0.004)^{* *}$ & 0.022 & $(0.004)^{* *}$ \\
\hline Mother's bargaining power & & & & & & & & & & & -0.014 & $(0.010)$ & -0.013 & $(0.010)$ \\
\hline \multicolumn{15}{|l|}{ Mother's working status } \\
\hline \multicolumn{15}{|l|}{ Did not work (Ref.) } \\
\hline Blue-collar workers & & & & & & & & & & & & & 0.001 & $(0.049)$ \\
\hline White-collar workers & & & & & & & & & & & & & -0.025 & $(0.042)$ \\
\hline \multicolumn{15}{|l|}{ Control variables } \\
\hline Mother's height & -0.002 & $(0.002)$ & -0.002 & $(0.002)$ & -0.002 & $(0.002)$ & -0.002 & $(0.002)$ & -0.002 & $(0.002)$ & -0.002 & $(0.002)$ & -0.002 & $(0.002)$ \\
\hline Mother's BMI & 0.059 & $(0.003)^{* *}$ & 0.059 & $(0.003)^{* *}$ & 0.059 & $(0.003)^{* *}$ & 0.059 & $(0.003)^{* *}$ & 0.059 & $(0.003)^{* *}$ & 0.059 & $(0.003)^{* *}$ & 0.059 & $(0.003)^{* *}$ \\
\hline Father's height & -0.001 & $(0.002)$ & -0.001 & $(0.002)$ & -0.001 & $(0.002)$ & -0.001 & $(0.002)$ & -0.001 & $(0.002)$ & -0.001 & $(0.002)$ & -0.001 & $(0.002)$ \\
\hline Father's BMI & 0.073 & $(0.004)^{* *}$ & 0.072 & $(0.004)^{* *}$ & 0.072 & $(0.004)^{* *}$ & 0.072 & $(0.004)^{* *}$ & 0.072 & $(0.004)^{* *}$ & 0.072 & $(0.004)^{* *}$ & 0.072 & $(0.004)^{* *}$ \\
\hline Sibling size & -0.030 & $(0.009)^{* *}$ & -0.030 & $(0.009)^{* *}$ & -0.030 & $(0.009)^{* *}$ & -0.029 & $(0.009)^{* *}$ & -0.029 & $(0.009)^{* *}$ & -0.029 & $(0.009)^{* *}$ & -0.029 & $(0.009)^{* *}$ \\
\hline PCE (million Rupiah) & 0.024 & $(0.009)^{*}$ & 0.023 & $(0.009)^{*}$ & 0.023 & $(0.009)^{*}$ & 0.023 & $(0.009)^{*}$ & 0.023 & $(0.009)^{*}$ & 0.023 & $(0.009)^{* *}$ & 0.023 & $(0.009)^{*}$ \\
\hline \multicolumn{15}{|l|}{ Adolescent activity } \\
\hline \multicolumn{15}{|l|}{$\begin{array}{l}\text { Neither went to school } \\
\text { nor work (Ref.) }\end{array}$} \\
\hline Went to school only & -0.283 & $(0.032)^{* *}$ & -0.288 & $(0.032)^{* *}$ & -0.288 & $(0.032)^{* *}$ & -0.291 & $(0.032)^{* *}$ & -0.286 & $(0.032)^{* *}$ & -0.286 & $(0.032)^{* *}$ & -0.286 & $(0.032)^{* *}$ \\
\hline Went to work only & -0.008 & $(0.039)$ & -0.006 & $(0.039)$ & -0.006 & $(0.039)$ & -0.014 & $(0.039)$ & -0.006 & $(0.039)$ & -0.005 & $(0.039)$ & -0.006 & $(0.039)$ \\
\hline $\begin{array}{l}\text { Went to school and } \\
\text { work }\end{array}$ & -0.171 & $(0.041)^{* *}$ & -0.174 & $(0.042)^{* *}$ & -0.174 & $(0.042)^{* *}$ & -0.187 & $(0.042)^{* *}$ & -0.181 & $(0.042)^{* *}$ & -0.181 & $(0.042)^{* *}$ & -0.182 & $(0.042)^{* *}$ \\
\hline
\end{tabular}







Compared with those who 'neither went to school or work', adolescents who 'went to school' or 'went to school and work' were significantly thinner (went to school only: $b=-0.283, p<0.01$; went to school and work: $b=-0.171, p<0.01)$. The BMI-for-age did not differ significantly by urban or rural residential location or by region. Interestingly, BMI-for-age in IFLS-3 (2000) and IFLS-4 (2007/2008) was significantly lower compared with BMI-for-age in IFLS-2 (1997/1998). In IFLS-5 (2014/2015), BMI-for-age was still lower than in IFLS-2 (1997/1998) but was not significant $(b=-0.034)$.

Models 2-4 in Table 3 show that there were no effects of women's empowerment on BMI-for-age. Inclusion of interaction terms between women's empowerment indicators and gender in Models 5-7 unveiled differences in the main effects, as well as in the interaction effects for mother's education. Model 6, which had the best fit (lowest $\mathrm{AIC}=50,452.564$ ), showed a smaller BMI-for-age gender gap for those who were raised by well-educated mothers as each additional year of schooling of the mothers increased the boys' BMI-for-age by $0.021 \mathrm{SD}(b=0.021, p<0.01)$.

Figure 1 depicts the predictive margins for the gendered difference in BMI-for-age by mother's education. The figure shows that the average BMI-for-age for Indonesian adolescent boys and girls was below zero standard deviations (SD) from the mean when compared with the WHO growth reference charts. Also, on average, boys were thinner than girls. This pattern was most clear for adolescents of less-educated mothers (mothers with 0 years of schooling: boys $=-0.865 \mathrm{SD}$; girls $=-0.458 \mathrm{SD}$ ). The gender gap in BMI-for-age was smaller for adolescents of better-educated mothers. However, being raised by a well-educated mother did not fully compensate adolescent boys' thinness lag (for adolescents with mothers who had 12 years of schooling: boys $=-0.696 \mathrm{SD}$; girls $=-0.549 \mathrm{SD})$. In fact, there was also a slight decrease in BMI-for-age for girls of mothers with more education (Model 6 in Table 4: $b=-0.008, p<0.05$ ). There were no gendered differences in BMI-for-age by mother's bargaining power and mother's working status.

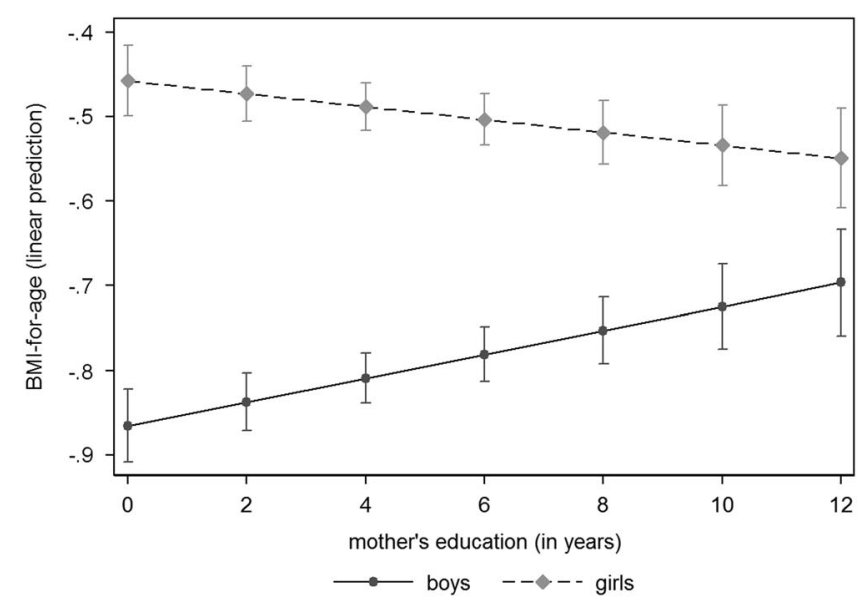

Fig. 1. BMI-for-age of adolescents by mother's education and gender. 


\section{Two-sample t-test}

Table 4 presents the food consumption differences between boys and girls by mother's education to understand how these might explain the interaction between mother's education and adolescents' BMI-for-age. For reasons of presentation and to allow $t$-test analysis, mother's education was collapsed into three categories: 'never went to school', '1-6 years of schooling' and 'more than 6 years of schooling'. There were clear patterns of gendered food consumption. In general, boys consumed less vegetables and fast food, but more instant noodles and soft drinks than girls ('all', $p<0.05$ ). Being raised by a mother with some years of schooling reduced the gender gap in vegetable and fruit consumption as it became non-significant. However, the fast-food consumption of

Table 4. Food consumption by gender and mother's education, $t$-test

\begin{tabular}{|c|c|c|c|c|c|c|c|c|c|}
\hline \multirow[b]{2}{*}{ Food type } & \multirow[b]{2}{*}{ Mother's education } & \multicolumn{3}{|c|}{ Boys } & \multicolumn{3}{|c|}{ Girls } & \multirow[b]{2}{*}{ Mean diff. } & \multirow[b]{2}{*}{$p$-value } \\
\hline & & Mean & SD & $n$ & Mean & SD & $n$ & & \\
\hline \multirow[t]{4}{*}{ Animal source } & Never went to school & 2.35 & $(1.38)$ & 2639 & 2.33 & $(1.37)$ & 2614 & 0.02 & 0.64 \\
\hline & $1-6$ years of schooling & 2.23 & $(1.32)$ & 1750 & 2.21 & $(1.32)$ & 1719 & 0.02 & 0.72 \\
\hline & $>6$ years of schooling & 2.67 & $(1.33)$ & 2249 & 2.64 & $(1.32)$ & 2047 & 0.03 & 0.46 \\
\hline & All & 2.42 & $(1.36)$ & 6638 & 2.40 & $(1.35)$ & 6380 & 0.03 & 0.24 \\
\hline \multirow[t]{4}{*}{ Vegetables } & Never went to school & 3.05 & $(1.57)$ & 2639 & 3.21 & $(1.58)$ & 2,614 & -0.16 & $<0.01$ \\
\hline & $1-6$ years of schooling & 2.61 & $(1.67)$ & 1750 & 2.70 & $(1.67)$ & 1,719 & -0.09 & 0.10 \\
\hline & $>6$ years of schooling & 2.59 & $(1.76)$ & 2249 & 2.68 & $(1.76)$ & 2047 & -0.09 & 0.11 \\
\hline & All & 2.78 & (1.68) & 6689 & 2.90 & (1.68) & 6436 & -0.12 & $<0.01$ \\
\hline \multirow[t]{4}{*}{ Fruits } & Never went to school & 1.77 & $(1.46)$ & 2639 & 1.84 & $(1.46)$ & 2614 & -0.08 & 0.05 \\
\hline & $1-6$ years of schooling & 1.42 & $(1.37)$ & 1750 & 1.33 & $(1.31)$ & 1719 & 0.08 & 0.07 \\
\hline & $>6$ years of schooling & 1.10 & (1.16) & 2249 & 1.10 & $(1.20)$ & 2047 & 0.00 & 0.96 \\
\hline & All & 1.45 & $(1.37)$ & 6689 & 1.47 & $(1.38)$ & 6436 & -0.02 & 0.51 \\
\hline \multirow[t]{4}{*}{ Milk } & Never went to school & 1.18 & $(2.15)$ & 2639 & 1.10 & $(2.13)$ & 2614 & 0.08 & 0.17 \\
\hline & $1-6$ years of schooling & 1.11 & $(2.05)$ & 1748 & 1.09 & $(2.07)$ & 1719 & 0.01 & 0.85 \\
\hline & $>6$ years of schooling & 2.01 & $(2.67)$ & 2248 & 1.99 & $(2.70)$ & 2047 & 0.02 & 0.77 \\
\hline & All & 1.44 & $(2.35)$ & 6686 & 1.37 & $(2.35)$ & 6436 & 0.06 & 0.13 \\
\hline \multirow[t]{4}{*}{ Snacks } & Never went to school & 3.07 & $(2.22)$ & 377 & 3.17 & $(2.14)$ & 346 & -0.10 & 0.53 \\
\hline & $1-6$ years of schooling & 3.11 & $(2.16)$ & 707 & 3.22 & $(2.21)$ & 731 & -0.11 & 0.32 \\
\hline & $>6$ years of schooling & 3.08 & (2.03) & 1227 & 3.20 & $(2.02)$ & 1098 & -0.12 & 0.15 \\
\hline & All & 3.08 & $(2.10)$ & 2321 & 3.19 & $(2.11)$ & 2186 & -0.11 & 0.07 \\
\hline \multirow[t]{4}{*}{ Fast food } & Never went to school & 0.29 & (1.03) & 377 & 0.44 & $(1.34)$ & 346 & -0.15 & 0.09 \\
\hline & $1-6$ years of schooling & 0.25 & $(0.91)$ & 707 & 0.37 & (1.15) & 732 & -0.12 & 0.03 \\
\hline & $>6$ years of schooling & 0.36 & $(1.02)$ & 1227 & 0.47 & $(1.15)$ & 1098 & -0.11 & 0.02 \\
\hline & All & 0.31 & (0.99) & 2321 & 0.43 & $(1.18)$ & 2187 & -0.11 & $<0.01$ \\
\hline \multirow[t]{4}{*}{ Instant noodles } & Never went to school & 2.36 & $(2.32)$ & 377 & 2.21 & $(2.15)$ & 346 & 0.15 & 0.38 \\
\hline & $1-6$ years of schooling & 2.47 & $(2.29)$ & 707 & 2.21 & $(2.18)$ & 732 & 0.26 & 0.03 \\
\hline & $>6$ years of schooling & 2.26 & $(2.03)$ & 1227 & 2.04 & $(1.95)$ & 1098 & 0.21 & 0.01 \\
\hline & All & 2.35 & $(2.17)$ & 2321 & 2.12 & $(2.06)$ & 2187 & 0.22 & $<0.01$ \\
\hline \multirow[t]{4}{*}{ Soft drinks } & Never went to school & 0.69 & $(1.35)$ & 376 & 0.42 & $(1.17)$ & 346 & 0.27 & $<0.01$ \\
\hline & $1-6$ years of schooling & 0.54 & $(1.28)$ & 708 & 0.42 & $(1.16)$ & 732 & 0.12 & 0.06 \\
\hline & $>6$ years of schooling & 0.60 & (1.19) & 1227 & 0.38 & $(1.02)$ & 1098 & 0.22 & $<0.01$ \\
\hline & All & 0.60 & $(1.24)$ & 2321 & 0.40 & (1.09) & 2187 & 0.19 & $<0.01$ \\
\hline
\end{tabular}

$\mathrm{SD}=$ standard deviation; mean diff. $=$ mean difference between boys and girls. 
boys whose mother had more than 6 years of schooling increased ('never went to school' $=0.29$ days vs 'more than 6 years of schooling' $=0.36$ days). When comparing boys and girls of mothers with some years of schooling, the boys' instant noodle consumption was significantly higher than that of the girls (' 1 to 6 years of schooling': boys $=2.47$ days vs girls $=2.21$ days, $p=0.03$; 'more than 6 years of schooling': boys $=2.26$ days vs girls $=2.04$ days, $p=0.01$ ). The gender gap in instant noodle consumption was not significant for adolescents who were raised by mothers who never went to school (boys $=2.36$ days vs girls $=2.21$ days, $p=0.38$ ). The $t$-test for soft drinks consumption of adolescents whose mother had 1-6 years of schooling was barely significant (boys $=0.54$ days vs girls $=0.42$ days, $p=0.06$ ), but the two other categories of mother's education showed significant $t$-test results. Thus, a gender difference in soft drinks consumption seemed to exist for all adolescents regardless of their mother's education. Overall, boys consumed soft drinks more often than girls ('all': boys $=0.59$ days; girls $=0.40$ days, $p<0.01$ ). Although no statistical tests were used to analyse non-gendered patterns of food consumption by mother's education, the diets of adolescents whose mothers had more schooling consisted more often of animal-source foods and milk, and less often of vegetables and fruit.

\section{Discussion}

This study of the association between women's empowerment and the nutritional status of adolescents in Indonesia found mixed results for the study's first hypothesis (Hypothesis I). While being raised by well-educated mothers was found to be positively correlated with adolescents' height-for-age, having a mother who had a blue-collar job was associated with shorter height. There were no significant effects of mother's bargaining power on adolescent nutritional status as indicated by height-for-age and BMI-for-age. However, there were interesting findings on gender inequalities in adolescent nutritional status in Indonesia. Similar to the patterns of undernourished adolescent boys in the WHO summary report on Asian societies (World Health Organization, 2006), this study found that Indonesian adolescent boys were on average thinner, i.e. had a lower BMI-for-age, than girls. In addition, a significant interaction between gender and mother's education was found for BMI-for-age. Being raised by a well-educated mother reduced the gap between boys and girls by increasing the BMI-forage of adolescent boys. Therefore, the gender gap in BMI-for-age was smaller for the adolescents of well-educated mothers, which firmly confirmed the study's second hypothesis (Hypothesis II). Further analyses unveiled gendered patterns of food consumption by mother's education. Despite the fact that adolescents of mothers who had some years of schooling consumed fewer vegetables and fruits than those whose mothers never went to school, their gender gap in BMI-for-age was smaller because the boys consumed more fast food and had higher instant noodle consumption than the girls.

Different indicators of women's empowerment were found to influence adolescent nutritional status in different ways. Mother's education was strongly linked to positive outcomes and more gender equality in nutritional status during adolescence. This justifies investment in girls' education as this may not only benefit their future labour market chances, but may also lead to positive outcomes for the health and nutritional 
status of their future children. However, the negative association between mother's working status, particularly for those with a blue-collar job, and adolescents' height-forage should be a matter of concern. It was not possible to examine the underlying causes for this negative association thoroughly. However, a blue-collar job is often associated with low socioeconomic status, as well as long and less-flexible working hours. This might leave blue-collar mothers with insufficient time and financial resources to supervise the eating patterns of their adolescent children, as has been found in previous studies of under-five children in Indonesia (Toyama et al., 2001; Roshita et al., 2013). The extensive consumption of fast food and instant noodles by Indonesian adolescents observed in this study is similar to the findings of the Baker and Friel (2014) study on the rise of processed food consumption and the nutrition transition in Asia. However, different to Baker and Friel (2014), this study unveiled gender differences in the consumption of these unhealthy, calorie-rich foods.

The positive association found in this Indonesian sample between mother's education and height-for-age in adolescents is similar to that reported by other studies on child nutrition (Thomas et al., 1991; Skoufias, 1999; Semba et al., 2008), indicating that the link between mother's education and height-for-age may extend into the adolescence period. However, unlike a study by Thomas et al. (2002), which found that mother's bargaining power affected child's health, this study found no evidence of a link between mother's bargaining power and adolescent nutritional status. One probable explanation for this might be the difference in how the bargaining power indicator was constructed. In this study, level of mother's bargaining power was derived from questions on household decision-making, whereas Thomas et al. (2002) used pre-marital resources. Considering that most Indonesian mothers have fairly high authority in domestic matters, variability in mother's bargaining power may not be sufficient to show an effect of this on adolescent nutritional status. Similar to the possible detrimental effect of mother's working status reported by Cunningham et al. (2015), this study observed a negative link between mother's working status and adolescent nutritional status. However, this study added more clarity and detailed information by showing that significant negative effects occurred only for height-for-age and only for adolescents whose mothers were blue-collar workers. The study also found that gender inequality in BMI-for-age was smaller for the adolescents of well-educated mothers. This result is similar to that of Bose (2011) in India, who reported that being raised by a more empowered mother reduced the gender gap in nutrition for under-five children. However, in contrast to Bose's study, in which empowered mothers were found to benefit their undernourished daughters by giving them a protein-rich diet, the present study indicated that the smaller gender gap in BMI-for-age might might be due to the unhealthy, calorie-rich diet of the boys of well-educated mothers, consisting of more fast food and instant noodles.

The study had some limitations. First, observations from all IFLS waves were merged to construct the analytical sample. While this approach increased the statistical power of the analyses, it restricted the ability to infer a causal effect. Future research should consider more rigorous methods which, for example, take time lags into account in order to establish the causal effects of women's empowerment on adolescent nutritional status with more certainty. A second important limitation is that previous studies have proposed that the effect of women's empowerment on child health might be 
overstated because certain indicators of women's empowerment, particularly mother's education, correlate with family SES (Parashar, 2005). Thus SES might confound the positive linkage between women's empowerment and nutritional status of adolescents. Although the study controlled for family SES by including Personal Consumption Expenditure (PCE), some bias might remain. The study shows that different indicators of women's empowerment may affect adolescents' nutritional status differently. However, since indicators of women's empowerment are multidimensional, future research should consider a broader set of indicators. For example mother's social capital has previously been shown to be an important channel through which a mother could improve her knowledge on nutrition and health behaviour (De Silva \& Harpham, 2007; Sujarwoto \& Tampubolon, 2013). This study focused on the anthropometric indicators of adolescent nutritional status. Future research might also examine other indicators such as haemoglobin level to gain a better understanding of nutritional status dynamics during adolescence. The food consumption analyses could also be improved using multivariate setups and controls for confounders related to food consumption patterns such as food availability (Hillbruner \& Egan, 2008), food prices (Beydoun et al., 2008; Grossman et al., 2014) and awareness of what a healthy diet is (Datar et al., 2014; Shin et al., 2014). The study concentrated on undernutrition, which is not the sole malnutrition problem in Indonesia. The double burden of over- and undernutrition among adults has been reported in a recent study in Indonesia, and this may extend to adolescents as well (Hanandita \& Tampubolon, 2015). Future research might examine to what extent women's empowerment could prevent malnutrition due to obesity among more affluent Indonesian groups. Another suggestion for future research is to examine how the negative effect on height-for-age of adolescents of blue-collar mothers could be prevented.

In conclusion, this study has shown that women's empowerment, particularly mother's education, positively affects the nutritional status of adolescents in Indonesia. It also indicated that there were smaller gender gaps in the nutritional status of adolescents raised by well-educated mothers. This finding may justify more investment in girls' education to benefit future generations, not only in childhood, but also may well extend into adolescence. However, the smaller gender gap could have been the result of the unhealthy weight gain of the adolescent boys of more educated mothers. Therefore, as well as the focus on girls, boys should be helped to adopt a healthier diet if the gender gap in adolescent nutritional status is to be reduced.

\section{Acknowledgments}

The authors thank the anonymous reviewers who have invested their time to help them improving the manuscript. An earlier version of this manuscript was presented at the Adolescence, Youth and Gender: Building Knowledge for Change Conference in Oxford, UK, 8-9th September 2016.

Ethical Approval. The authors assert that all procedures contributing to this work comply with the ethical standards of the relevant national and institutional committees on human experimentation and with the Helsinki Declaration of 1975, as revised in 2008 . 
Conflicts of Interest. The authors have no conflicts of interest to declare.

Funding. The Indonesian government funded this study through BPP-LN DIKTI grant number 124.15/E4.4/2014.

\section{References}

Badan, Pusat Statistik (2011) Kewarganegaraan, suku Bangsa, agama, dan bahasa sehari-hari penduduk Indonesia: Hasil Sensus Penduduk 2010. Badan Pusat Statistik, Jakarta.

Baker, P. \& Friel, S. (2014) Processed foods and the nutrition transition: evidence from Asia. Obesity Reviews 15, 564-577.

Beegle, K., Frankenberg, E. \& Thomas, D. (1999) Measuring Change in Indonesia. RAND Corporation, Santa Monica.

Beydoun, M.A., Powell, L. M. \& Wang, Y. (2008) The association of fast food, fruit and vegetable prices with dietary intakes among US adults: is there modification by family income? Social Science \& Medicine 66, 2218-2229.

Booth, A. L. \& Kee, H. J. (2009) Birth order matters: the effect of family size and birth order on educational attainment. Journal of Population Economics 22, 367-397.

Bose, S. (2011) The effect of women's status and community on the gender differential in children's nutrition in India. Journal of Biosocial Science 43, 513-533.

Bras, H., Kok, J. \& Mandemakers, K. (2010) Sibship size and status attainment across contexts: evidence from the Netherlands, 1840-1925. Demographic Research 23, 73-104.

Bronte-Tinkew, J. \& Dejong, G. (2004) Children's nutrition in Jamaica: do household structure and household economic resources matter? Social Science \& Medicine 58, 499-514.

Burroway, R. (2016) Gender and food: from production to consumption and after. Advances in Gender Research 22, 117-142.

Cai, W. (2014) Nutritional challenges for children in societies in transition. Current Opinion in Clinical Nutrition and Metabolic Care 17, 278-284.

Cameron, A. C., Gelbach, J. B. \& Miller, D. L. (2011) Robust inference with multiway clustering. Journal of Business \& Economic Statistics 29, 238-249.

Cunningham, K., Ruel, M., Ferguson, E. \& Uauy, R. (2015) Women's empowerment and child nutritional status in South Asia: a synthesis of the literature. Maternal \& Child Nutrition 11, 1-19.

Dasgupta, S. (2016) Son preference and gender gaps in child nutrition: does the level of female autonomy matter? Review of Development Economics 20, 375-386.

Datar, A., Nicosia, N. \& Shier, V. (2014) Maternal work and children's diet, activity, and obesity. Social Science \& Medicine 107, 196-204.

De Silva, M. J. \& Harpham, T. (2007) Maternal social capital and child nutritional status in four developing countries. Health and Place 13, 341-355.

Delfino, B. M., Campos, R. G., Pereira, T. M., Mantovani, S. A. S., Oliart-Guzman, H., Martins, A. C. et al. (2016) Evolution of socioeconomic conditions and its relation to spatialtemporal changes of giardiasis and helminthiasis in Amazonian children. Ecohealth 13, 743-760.

Engle, P. L., Menon, P. \& Haddad, L. (1999) Care and nutrition: concepts and measurement. World Development 27, 1309-1337.

Filmer, D. \& Pritchett, L. H. (2001) Estimating wealth effects without expenditure data or tears: an application to educational enrollments in states of India. Demography 38(1), 115-132.

Frankenberg, E., Beegle, K., Thomas, D. \& Suriastini, W. (1999) Health, education, and the economic crisis in Indonesia. In Annual Meeting of the Population Association America, New York, March 1999, pp. 25-27.

Frankenberg, E. \& Thomas, D. (2001) Measuring Power. Food Consumption and Nutrition Division, International Food Policy Research Institute, Washington, DC. 
George, C. (1968) The Indianized States of South-East Asia. University of Hawaii Press, Honolulu.

Glewwe, P. (1999) Why does mother's schooling raise child health in developing countries? Evidence from Morocco. Journal of Human Resources 34, 124-159.

Grossman, M., Tekin, E. \& Wada, R. (2014) Food prices and body fatness among youths. Economics and Human Biology 12, 4-19.

Guilmoto, C. Z. (2015) Mapping the diversity of gender preferences and sex imbalances in Indonesia in 2010. Population Studies 69, 299-315.

Gumus, S. G. \& Wingenbach, G. (2016) The child labor problem in Turkish agriculture: what can we do? Social Indicators Research 127, 1193-1215.

Hanandita, W. \& Tampubolon, G. (2015) The double burden of malnutrition in Indonesia: social determinants and geographical variations. SSM-Population Health 1, 16-25.

Heilmann, S. (2013) Life-chances of children in Indonesia: the links between parental resources and children's outcomes in the areas of nutrition, cognition and health. Dissertation, London School of Economics and Political Science (LSE).

Hillbruner, C. \& Egan, R. (2008) Seasonality, household food security, and nutritional status in Dinajpur, Bangladesh. Food and Nutrition Bulletin 29, 221-231.

Kabeer, N. (1999) Resources, agency, achievements: reflections on the measurement of women's empowerment. Development and Change 30, 435-464, p. 437.

Kevane, M. \& Levine, D. I. (2000) The Changing Status of Daughters in Indonesia. Institute for Research on Labor and Employment, UC Berkeley.

Khatun, M., Stenlund, H. \& Hörnell, A. (2004) BRAC initiative towards promoting gender and social equity in health: a longitudinal study of child growth in Matlab, Bangladesh. Public Health Nutrition 7, 1071-1079.

Koolwal, G. B. (2007) Son preference and child labor in Nepal: the household impact of sending girls to work. World Development 35, 881-903.

Liu, Q., Yu, C., Gao, W., Cao, W., Lyu, J., Wang, S. et al. (2015) Genetic and environmental effects on weight, height, and BMI under 18 years in a Chinese population-based twin sample. Twin Research and Human Genetics 18, 571-580.

Malhotra, A. \& Schuler, S. R. (2005) Women's empowerment as a variable in international development. In Narayan, D. (eds) Measuring Empowerment: Cross-Disciplinary Perspectives. World Bank, Washington, DC, pp. 71-88.

Miller, J. E. \& Rodgers, Y. V. (2009) Mother's education and children's nutritional status: new evidence from Cambodia. Asian Development Review 26, 131-165.

Ministry of Health Republic of Indonesia (2013) Riset kesehatan dasar 2013. Badan Penelitian dan Pengembangan Kesehatan Kementerian Kesehatan RI, Jakarta.

Mosedale, S. (2005) Assessing women's empowerment: towards a conceptual framework. Journal of International Development 17, 243-257.

Niehof, A. \& Lubis, F. (eds) (2003) Two is Enough: Family Planning in Indonesia Under the New Order 1968-1998. KITLV Press, Leiden.

Odutolu, O., Adedimeji, A., Odutolu, O., Baruwa, O. \& Olatidoye, F. (2003) Economic empowerment and reproductive behaviour of young women in Osun state, Nigeria. African Journal of Reproductive Health 7, 92-100.

Onis, M., Onyango, A. W., Borghi, E., Siyam, A., Nishida, C. \& Siekmann, J. (2007) Development of a WHO growth reference for school-aged children and adolescents. Bulletin of the World Health Organization 85, 660-667.

Pande, R. (2003) Selective gender differences in childhood nutrition and immunization in rural India: the role of siblings. Demography 40, 395-418.

Parashar, S. (2005) Moving beyond the mother-child dyad: women's education, child immunization, and the importance of context in rural India. Social Science \& Medicine 61, 989-1000. 
Pepper, J. V. (2002) Robust inferences from random clustered samples: an application using data from the panel study of income dynamics. Economics Letters 75, 341-345.

Phan, L. (2016) Measuring women's empowerment at household level using DHS data of four Southeast Asian countries. Social Indicators Research 126, 359-378.

Popkin, B. M., Adair, L. S. \& Ng, S. W. (2012) Global nutrition transition and the pandemic of obesity in developing countries. Nutrition Reviews 70, 3-21.

Rashed, S., Johnson, H., Dongier, P., Moreau, R., Lee, C., Crepeau, R. et al. (1999) Determinants of the permethrin impregnated bednets (PIB) in the Republic of Benin: the role of women in the acquisition and utilization of PIBs. Social Science \& Medicine 49, 993-1005.

Reid, A. (1988) Female roles in pre-colonial Southeast Asia. Modern Asian Studies 22, 629-645.

Richards, E., Theobald, S., George, A., Kim, J. C., Rudert, C., Jehan, K. \& Tolhurst, R. (2013) Going beyond the surface: gendered intra-household bargaining as a social determinant of child health and nutrition in low and middle income countries. Social Science \& Medicine 95, 24-33.

Riyadi, H., Khomsan, A., Dadang, S., Faisal, A. \& Mudjajanto, E. S. (2006) Studi tentang status gizi pada rumah tangga miskin dan tidak miskin. Gizi Indonesia 29(1), 33-46.

Rodenburg, J., Koning, J. \& Nolten, M. (2000) Women and Households in Indonesia: Cultural Notions and Social Practices. Curzon Press, Richmond, Surrey, UK.

Roshita, A., Page, A., Schubert, L. \& Whittaker, M. (2013) Maternal working characteristics is associated with child underweight in urban middle-class families of Indonesia. Annals of Nutrition and Metabolism 63, 763-763.

Semba, R. D., Pee, S., Sun, K., Sari, M., Akhter, N. \& Bloem, M. W. (2008) Effect of parental formal education on risk of child stunting in Indonesia and Bangladesh: a cross-sectional study. The Lancet 371, 322-328.

Sen, A. (2001) Development as Freedom (2nd edition). Oxford University Press, New York.

Shahabuddin, A. K., Talukder, K., Talukder, M. K., Hassan, M., Seal, A., Rahman, Q. et al. (2000) Adolescent nutrition in a rural community in Bangladesh. Indian Journal of Pediatrics 67(2), 93-98.

Shin, H. J., Cho, E., Lee, H. J., Fung, T. T., Rimm, E., Rosner, B. et al. (2014) Instant noodle intake and dietary patterns are associated with distinct cardiometabolic risk factors in Korea. Journal of Nutrition 144(8), 1247-1255.

Shroff, M. R., Griffiths, P. L., Suchindran, C., Nagalla, B., Vazir, S. \& Bentley, M. E. (2011) Does maternal autonomy influence feeding practices and infant growth in rural India? Social Science \& Medicine 73, 447-455.

Silventoinen, K., Bartels, M., Posthuma, D., Burk, G. F. E., Willemsen, G., van Beijsterveldt, T. C. E. M. \& Boomsma, D. I. (2007) Genetic regulation of growth in height and weight from 3 to 12 years of age: a longitudinal study of Dutch twin children. Twin Research and Human Genetics 10, 354-363.

Skoufias, E. (1999) Parental education and child nutrition in Indonesia. Bulletin of Indonesian Economic Studies 35, 99-119.

Smith, L. C. (2003) The Importance of Women's Status for Child Nutrition in Developing Countries. International Food Policy Research Institute, Washington, DC.

Smith, L. C. \& Haddad, L. J. (2000) Explaining Child Malnutrition in Developing Countries: A Cross-Country Analysis. International Food Policy Research Institute, Washington, DC.

Stoler, A. (1977) Class structure and female autonomy in rural Java. Signs 3, 74-89.

Stradford, L., Poppel, F. \& Lumey, L. H. (2016) Can resource dilution explain differences in height by birth order and family size? A study of 389,287 male recruits in twentieth-century Netherlands. History of the Family 22, 214-235.

Strauss, J., Beegle, K., Dwiyanto, A., Herawati, Y., Pattinasarany, D., Satriawan, E. et al. (2004) Indonesian Living Standards: Before amd After the Financial Crisis. RAND Corporation, Santa Monica. 
Strauss, J., Witoelar, F. \& Sikoki, B. (2016) The Fifth Wave of the Indonesia Family Life Survey: Overview and Field Report. RAND Corporation, Santa Monica.

Sujarwoto, S. \& Tampubolon, G. (2013) Mother's social capital and child health in Indonesia. Social Science \& Medicine 91, 1-9.

Suryadarma, D., Widyanti, W., Suryahadi, A. \& Sumarto, S. (2006) From Access to Income: Regional and Ethnic Inequality in Indonesia. SMERU Research Institute, Jakarta.

The Lancet (eds) (2013) Adolescence: a second chance to tackle inequities. The Lancet 382, 1535.

Thomas, D. (1994) Like father, like son; like mother, like daughter: parental resources and child height. Journal of Human Resources 29, 950-988.

Thomas, D., Contreras, D. \& Frankenberg, E. (2002) Distribution of Power Within the Household and Child Health. RAND Corporation, Santa Monica.

Thomas, D., Strauss, J. \& Henriques, M. H. (1991) How does mother's education affect child height? Journal of Human Resources 26, 183-211.

Toyama, N., Wakai, S., Nakamura, Y. \& Arifin, A. (2001) Mother's working status and nutritional status of children under the age of 5 in urban low-income community, Surabaya, Indonesia. Journal of Tropical Pediatrics 47, 179-181.

Vijayaraghavan, K., Venkaiah, K., Damayanthi, K. \& Nayak, M. U. (2000) NNMB Report on Diet \& Nutritional Status of Adolescents. National Institute of Nutrition, India.

Viner, R. M., Ozer, E. M., Denny, S., Marmot, M., Resnick, M., Fatusi, A. \& Currie, C. (2012) Adolescence and the social determinants of health. The Lancet 379, 1641-1652.

Wang, Y. \& Chen, H. J. (2012) Use of percentiles and z-scores in anthropometry. In Handbook of Anthropometry. Springer, New York, pp. 29-48.

Witoelar, F. (2009) Note to the Construction of the IFLS Consumption Expenditure Aggregates. World Bank Research.

Wolff, F. C. \& Maliki (2008) Evidence on the impact of child labor on child health in Indonesia, 1993-2000. Economics and Human Biology 6, 143-169.

World Bank (2017) Indonesia. URL: http://data.worldbank.org/country/indonesia (accessed $7^{\text {th }}$ May 2017).

World Health Organization (2006) Adolescent Nutrition: A Review of the Situation in Selected South-East Asian Countries. WHO Regional Office for South-East Asia, New Delhi. 